\title{
Overview of Sugar Industry in Kenya and Prospects for Production at the Coast
}

\author{
Bancy M. Mati' ${ }^{1}$ Michael K. Thomas ${ }^{2}$ \\ ${ }^{1}$ Jomo Kenyatta University of Agriculture and Technology (JKUAT), Nairobi, Kenya \\ ${ }^{2}$ Rural Focus Limited, Nanyuki, Kenya \\ Email: b.mati@jkuat.ac.ke, mike@ruralfocus.com
}

How to cite this paper: Mati, B.M. and Thomas, M.K. (2019) Overview of Sugar Industry in Kenya and Prospects for Production at the Coast. Agricultural Sciences, 10, 1477-1485.

https://doi.org/10.4236/as.2019.1011108

Received: October 16, 2019

Accepted: November 19, 2019

Published: November 22, 2019

Copyright $\odot 2019$ by author(s) and Scientific Research Publishing Inc. This work is licensed under the Creative Commons Attribution International License (CC BY 4.0).

http://creativecommons.org/licenses/by/4.0/

\begin{abstract}
This paper utilized national data obtained mainly from published sources as well as information obtained from field visits, key informant interviews, reports and records in the coastal region of Kenya. It is a sector review of the sugar industry in Kenya, with special focus on opportunities for expanding production in the coastal region. Sugar, or sugarcane (Saccharum Hybrids spp.) is among the top six commercial crops grown in Kenya. The others are tea, cut flowers, vegetables, coffee and maize. Industrial sugar was introduced in Kenya in 1902 and the first processing factory opened in 1922. In the 1960s, new government policy encouraged expansion of commercial sugar production with new factories opening in western Kenya. By the mid-1970s, Kenya was a sugar exporter. But from the 1980s, the sugar sector started to decline both in production and profitability, with the country becoming a net sugar importer by the 1980s. Although the area under sugarcane has expanded over the years to cover 220,000 ha, productivity is low achieving only 55 tonnes/hectare. Meanwhile, production costs have been increasing, averaging US $\$ 1007 /$ tonnes in 2018 . Over 80 percent of the sugar is grown rainfed by smallholder farmers mostly in western Kenya using low inputs, with consequent poor productivity. The sugar sector has numerous challenges including: agronomic, technological, economic, management and policy limitations. This paper traces the main issues impacting the sugar industry in Kenya. It finds a sector in turmoil that requires significant reforms. It explores prospects of the next sugar revolution emerging from the coast. The coastal region has land available for rainfed and irrigated sugarcane, a warmer climate and possibilities to grow short-maturing cane varieties of higher sucrose concentrations. But other constraints are also inherent at the coast. These must be overcome for sugar to become a major cash crop in the region.
\end{abstract}

\section{Keywords}

Sugar, Industry, Production, Kenya, Coastal Region 


\section{Evolution of the Sugar Industry in Kenya}

Sugarcane (Saccharum Hybrids spp.) was an indigenous crop grown in Kenya before the advent of the colonial era. Local sugarcane varieties were grown by agrarian communities along riparian lands. The crop was chewed as food or used in making traditional beer [1]. Sugarcane as an industrial crop was introduced in Kenya in 1902, when the first trials were planted in Kisumu [2]. The first sugar factory was established at Miwani, near Kisumu, in 1922 [3]. Policies on sugar production from the early 1900s up to independence in 1963 were based on colonial law, which dictated that only Asians were allowed to grow sugar. The policy reforms of the Swynerton Plan [4] which allowed Africans to grow certain cash crops did not affect sugar. That changed with the enactment of Sessional Paper No. 10 of 1965 [5], which allowed Africans to grow industrial sugar.

After independence in the 1960s, the government decided to invest in sugar factories, mostly in western Kenya. Sugar production increased between 1966 and 1980 [2]. In 1973, the Government established the Kenya Sugar Authority (KSA). By 1976, domestic sugar production had reached 296,000 tonnes while consumption was 253,000 tonnes [6]. However, this trend was short-lived as Kenya soon became a net sugar importer. For instance, between 1981 and 2004, total sugar production grew from 368,970 tonnes to 517,000 tonnes while domestic sugar consumption increased from 324,054 tonnes to 669,914 tonnes [7]. By 2015, there were 15 sugar factories in Kenya with a milling capacity exceeding 6 million tonnes/year, but available cane was 5,407,427 tonnes/year (Table 1). To date, sugar production has remained below the milling capacities.

\section{Data Collection and Sources}

This paper utilized national data and information obtained from both primary and secondary sources in Kenya. These included published government record and reports as well as review of global literature. The primary data were collected between 2017 and 2018, from the coastal region in Kenya through field visits, key informant interviews, meetings and review of records and reports at Kwale International Sugar Company Limited (KISCOL), Sugar Research Institute (SRI) based at Mtwapa and County Government offices at Kwale and Kilifi.

\section{Contemporary Status of the Sugar Sector in Kenya}

\subsection{Sugar Production}

Currently, sugar is grown mainly in western Kenya around Nyando, Migori, Mumias, Busia, Nandi and the coastal region. There are about 250,000 smallscale sugarcane farmers who supply most of the cane milled in Kenya. The sugar industry supports the livelihoods of about six million Kenyans directly or indirectly, contributing to rural household economies [10].

Sugar is among the top commercial crops in Kenya, alongside tea, coffee, 
Table 1. Sugar factories establishment in Kenya and their capacities.

\begin{tabular}{|c|c|c|c|c|c|}
\hline No. & Name of Sugar factory & $\begin{array}{c}\text { Year } \\
\text { Established }\end{array}$ & $\begin{array}{c}\text { Area under } \\
\text { cane (ha) } \\
(2015 / 2016)\end{array}$ & $\begin{array}{c}\text { Mill Capacity } \\
\text { (tonnes) } \\
(2015 / 2016)\end{array}$ & $\begin{array}{c}\text { Available } \\
\text { cane (tonnes) } \\
(2015 / 2016)\end{array}$ \\
\hline 1. & Miwani Sugar Company & 1922 & 1860 & - & 28,718 \\
\hline 2. & Muhoroni Sugar Company & 1964 & 17,503 & 360,800 & 339,258 \\
\hline 3. & Chemelil Sugar Company & 1965 & 18,442 & 451,000 & 187,234 \\
\hline 4. & Mumias sugar factory & 1973 & 36,582 & 1,312000 & $1,054,759$ \\
\hline 5. & Nzoia Sugar Factory & 1978 & 29,022 & 492,000 & 807,651 \\
\hline 6. & South Nyanza Sugar Factory & 1979 & 16,186 & 410,000 & 475,900 \\
\hline 7. & West Kenya Sugar Company & 1981 & 30,104 & 688,800 & 734,609 \\
\hline 8. & Butali Sugar Mills & 2005 & 29,551 & 410,000 & 479,311 \\
\hline 9. & Soin Sugar Factory & 2006 & 1769 & 24,600 & 28,929 \\
\hline 10. & $\begin{array}{c}\text { Kibos Sugar \& } \\
\text { Allied Industries }\end{array}$ & 2007 & 6847 & 492,000 & 149,016 \\
\hline 11. & $\begin{array}{l}\text { Kwale International Sugar } \\
\text { Company Limited (KISCOL) }\end{array}$ & 2007 & 5500 & 295,200 & 274,316 \\
\hline 12. & Busia Sugar company & 2008 & & & \\
\hline 13. & Kisii Sugar Factory & 2009 & & & \\
\hline 14. & Transmara Sugar company & 2011 & 16,445 & 656,000 & 615,176 \\
\hline \multirow[t]{2}{*}{15.} & Sukari Industries Limited & 2011 & 9155 & 459,200 & 232,552 \\
\hline & Total (tonnes) & & 218,966 & $6,051,600$ & $5,407,427$ \\
\hline
\end{tabular}

Data sources: [8] and [9].

flowers, vegetables and maize [11]. The area under sugarcane in Kenya is about 202,000 ha, with total production averaging 5.262 million tonnes of cane supplied to factories per year (Table 2). In addition, average yields of sugarcane have been declining from about $66.4 \mathrm{t} / \mathrm{ha}$ in 2015 to $55.1 \mathrm{t} / \mathrm{ha}$ in 2018 (Table 2). This compares poorly with the global average of $63 \mathrm{t} / \mathrm{ha}$ [10]. Reasons for the reduction in productivity include; low quality sugarcane varieties, poor agronomic management, high cost of inputs practices, delayed harvesting and disillusionment from the industry [12].

\subsection{Sugar Imports and Exports}

In recent years, sugar production has declined from about 635,700 tonnes in 2015 to 491,100 tonnes in 2018 of milled sugar. Meanwhile, sugar imports have been increasing (Table 3). The annual domestic demand is over 900,000 tonnes, meaning the country is a net importer of sugar. Even then, Kenya exports small quantities of sugar mostly to South Sudan and Somalia. Marketed sugar is mostly for domestic consumption, generating about USD5 billion annually [13], underpinning the importance of the sugar sector. 
Table 2. Sugarcane production trends in Kenya for the period 2014-2018.

\begin{tabular}{cccccc}
\hline Sugarcane Area and production & $\mathbf{2 0 1 4}$ & $\mathbf{2 0 1 5}$ & $\mathbf{2 0 1 6}$ & $\mathbf{2 0 1 7}$ & $\mathbf{2 0 1 8}$ \\
\hline Area under cane ('000 Ha) & 211.3 & 223.6 & 220.8 & 191.2 & 202.4 \\
Area harvested ('000 ha) & 72.2 & 77.8 & 85.8 & 67.7 & 73.1 \\
Total Production ('000 tonnes) & 6409.9 & 7164.8 & 7151.7 & 4751.6 & 5262.2 \\
Production non-contracted farms ('000 tonnes) & 1977.1 & 1995.8 & 1816.7 & 1004.3 & 1233.1 \\
Average yield (tonnes/ha) & 61.4 & 66.4 & 62.2 & 55.3 & 55.1 \\
\hline
\end{tabular}

Source: [9].

Table 3. Production, imports and exports of sugar in Kenya, 2014-2018.

\begin{tabular}{cccc}
\hline Year & Production (tonnes) & Imports (tonnes) & Exports (tonnes) \\
\hline 2014 & 592,700 & 192,100 & 400 \\
2015 & 635,700 & 247,400 & 100 \\
2016 & 639,700 & 334,100 & 100 \\
2017 & 376,100 & 989,600 & 400 \\
2018 & 491,100 & 284,200 & 2000 \\
\hline
\end{tabular}

Source: [13].

\subsection{Sugar Distribution and Marketing}

Processed sugar in Kenya reaches consumers through a network of wholesalers, retailers, importers and distributors. The ex-factory price paid by wholesalers incorporates the cost of the sugarcane, milling, processing, factory operations, packaging, retailers' profits and government levies, which include a 16 percent Value Added Tax (VAT) and a 4 percent Sugar Development Levy (SDL) imposed by the KSB [14]. The average ex-factory price of sugar in Kenya is about US $\$ 800$ per tonne, which compares poorly with world market price of US\$280 per tonne [15]. This means that Kenyan consumers pay too much for sugar.

According to the Agriculture and Food Authority [16], some 56 companies are registered as sugar importers. Thus, importers are more than all the sugar factories in Kenya combined. Quite often, domestic sugar prices are inflated, partly due to tariffs and quotas applied to Kenya's raw sugar imports, making sugar expensive. Most retail stores undertake in-house packaging and branding. Retail sugar prices range between USD1.20 to USD1.50 per kilogram. With a production price of at least USD $0.8 / \mathrm{kg}$, most local millers cannot make a profit due to high overhead costs, resulting in cash-flow problems [14]. The poor oversight of sugar importation leads to unrealistic profit margins for importers compared to locally produced sugar [17].

\subsection{Challenges Facing the Sugarcane Sector in Kenya}

Sugarcane production in Kenya has declined due to several challenges. At the farm level, sugar productivity is low due to poor seed of long maturing varieties, 
smut disease, high costs of inputs and delayed payments to farmers [18]. Sugarcane in western Kenya takes 18 to 24 months in the field. By contrast Sudan grows early maturing cane varieties that mature within 14 months. Also, the production costs of sugar have increased, from about US\$676 per tonne in 2014 to US\$1007 per tonne in 2018. This compares poorly with production costs of USD 350 per tonne in Malawi and USD 400 per tonne in Zambia.

In the sugar factories, mismanagement has contributed to inefficiencies [10]. Most of the state-owned sugar mills are operating below capacity and are burdened by huge debts. They have inefficient, poorly maintained machinery which suffer frequent breakdowns [19]. Although the Government has privatized most of the sugar factories, e.g. Mumias, they still make losses. As a result, locally produced sugar remains uncompetitive with the cost of production reportedly being 60 percent higher than in Uganda and Tanzania, and 50 per cent higher than in Zambia [20]. Instability in world sugar prices and trade barriers impact the sugar industry [19] which also faces competition from low-cost sugar produced within COMESA and low world market prices [6].

Another problem facing the sugar industry is corruption and mismanagement of the institutions in the sugar-sub-sector [21]. The issues range from tendering, issuance of licenses, sugar importers, milling factories and traders [22]. Political interference in the appointment of managers of milling firms has led to lack of professionalism and accountability in management boards and importation of illegal sugar, distorting business [21]. Therefore, unless and until corruption and mismanagement are tackled across all levels, the sugar industry in Kenya will continue to decline.

\section{Consideration for Sugar Production beyond Western Kenya}

Western Kenya is the largest producer of sugar in Kenya, supporting about 170,000 smallholder farming households. About 80 percent of sugar production in Kenya is from smallholder farms. In some areas, sugarcane covers three times more land than other crops [23].

The land holdings under smallholder sugarcane in western Kenya are getting smaller due to redistribution and fragmentation [24]. In Nyando, the average farm family has about 2 acres ( 0.8 ha) of land. By contrast, out-growers at Ramisi at the coast have at least 50 acres (20 ha). Generally, the sugar industry has led to increased poverty for smallholder farmers in western Kenya. There is need to look elsewhere for improving production.

\section{Opportunities for Sugar Production at the Coastal Region}

There are unexploited opportunities for both rainfed and irrigated sugar production in the coastal region of Kenya [25]. In Kwale County, rainfed sugarcane growing is practiced around Ramisi, where about 10,000 ha is under cultivation. The Ramisi area is sub-humid, receiving about $1100 \mathrm{~mm}$ annual rainfall, which 
falls in about 9 months between January and September. Generally, sugarcane requires $1500 \mathrm{~mm}$ /year of rain, meaning that although sugar will grow around Ramisi, the crop suffers moisture stress during the dry season.

In terms of land potential, sugar production could expand to Tana delta areas, but it requires irrigation. The Tana Delta has fertile loam soils that hold water much better than the sands found in Ramisi. Due to the hot climate, cane varieties that mature at $10-12$ months are possible and unpublished reports indicate that yields can be as high as $200 \mathrm{t} / \mathrm{ha}$. However, water scarcity is a major challenge, and is one of the reasons the potential has not been exploited.

Irrigated sugar production is possible in much of the coastal region. There is potential in the middle Tana sub-zones and Tana Delta using water from the Tana River [26]. In Tana delta, irrigated sugarcane requires about $20,000 \mathrm{~m}^{3} / \mathrm{ha} /$ annum of water [27]. Direct river diversion could irrigate about 15,000 hectares, but this area could be increased to 40,000 hectares of sugarcane if water storage and efficient irrigation methods were applied.

Based on information obtained from discussions with the Manager of the Sugar Research Institute based at Mtwapa in the coast, early maturing sugarcane varieties are suited to the coastal region. Here, the first crop matures after 12 months, while the ratoon crop matures after 10 months. The minimum water requirement for sugarcane at the Kenyan coast is about $7 \mathrm{~mm} /$ day, assuming drip irrigation (i.e. minimum losses). Another advantage is that sugarcane once planted can be harvested over a long period, for about 7 to 8 years, on cutting back each year.

However, there are challenges to the expansion of sugarcane at the coast. For instance, sugar cane farming is considered a threat to the natural ecosystems such as the mangroves, forests and endemic wildlife species [28]. Conservation groups opposed large-scale sugar plantations in the Tana Delta, e.g. the proposed Tana Integrated Sugar Project [27], as the delta holds unique flora and fauna, and was designated a Ramsar site in 2012. In 2008 Kenyan conservationists prevented Mumias Sugar Company from developing a sugarcane farm in excess of 20,000 ha in the Tana Delta wetland [29]. Moreover, some areas further north of the Delta suffer insecurity due to banditry and terrorism. These factors have discouraged would-be investors. As a result, not much investment has gone into sugar plantations in the coastal areas.

\section{Conclusions and Recommendations}

The demand for sugar in Kenya is growing and the crop can be grown in the country. At the same time, the sugar industry requires a number of reforms to turn it around and to improve productivity and profitability. There is need to motivate smallholder out-growers by revamping extension services, improving cane varieties, field operations, transport, marketing and timely payments. Generally, the laws to protect farmers or support the sugar industry exist. What has been lacking is professionalism and accountability across all levels of the sugar 
value chain. The revised Crops Act [30] covering regulations for the sugar sector have been enacted, but it has to be fully applied. There is need for overhaul of the sector to enforce laws and best practices.

There is scope to expand sugar production in the Kenyan coastal region. However, a number of issues must first be resolved such as land rights, developing irrigation infrastructure, improving in-field water management and developing viable sugar value chain to include: input and output markets, factories, transport, socio-economic safeguards, policy and institutional support, for sugar production to be sustainable.

\section{Acknowledgements}

The authors gratefully acknowledge the support from the Gro for GooD research project team (University of Oxford, Rural Focus Ltd, University of Nairobi, Jomo Kenyatta University of Agriculture and Technology, Universitat Politècnica de Catalunya UPC), the Water Resources Authority (WRA), Base Titanium Ltd, Kwale, International Sugar Company (KISCOL) and Kenya Meteorological Department (KMD) for their support during the study. The UPGRO research project was financed by the UK's Department for International Development (DFID), and the Natural Environment Research Council (NERC).

\section{Conflicts of Interest}

The authors declare no conflicts of interest regarding the publication of this paper.

\section{References}

[1] Barnes, A.C. (1953) Cane Sugar in East Africa. http://www.sasta.co.za/wp-content/uploads/Proceedings/1950s/1953_Barnes_Cane \%20Sugar\%20In\%20East.pdf

[2] Wanyande, P. (2001) Management Politics in Kenya's Sugar Industry: Towards an Effective Framework. African Association of Political Science, 6, 123-140.

[3] Odada, J.E. (1986) Incentives and Management for an Integrated Agro-Industry: Sugar and Sugarcane in Kenya. Report Submitted to the World Bank.

[4] Swynerton, R.J.M. (1955) A Plan to Intensify the Development of African Agriculture in Kenya. Colony and Protectorate of Kenya. Government Printer, Nairobi.

[5] Republic of Kenya (1965) African Socialism and Its Application to Planning in Kenya. Government Printer.

[6] Institute of Economic Affairs (2005) What Ails the Sugar Industry in Kenya? Trade Notes. Issue 8: August 2005, Nairobi.

[7] Maina, L., Netondo, W. and Wekesa, A. (2011) Historical Development of Commercial Sugarcane Farming in the Lake Victoria Basin, In: Commercial Sugarcane Farming. A Quandary of Opportunities in the Lake Victoria Basin, Fountain Publishers, Kampala.

[8] Sugar History. Sugar Research Institute. http://www.kalro.org/sugar/?q=sugar-history 
[9] Agriculture and Food Authority [AFA] (2015) Cane Availability Survey 2015/1616/17 Report. Sugar Directorate.

[10] Kenya National Assembly [KNA] (2015) Parliamentary Report of the Departmental Committee on Agriculture, Livestock and Co-Operatives on the Crisis Facing the sugar industry in Kenya. Kenya National Assembly, Eleventh Parliament (3rd Session-2015), Nairobi.

[11] Ministry of Agriculture, Livestock, Fisheries and Irrigation (2019) Agricultural Transformation and Growth Strategy (ASTGS) 2019-2029. Republic of Kenya.

[12] Kenya Sugar Board [KSB] (2009) Kenya Sugar Board Strategic Plan 2009. http://www.kenyasugar.co.ke/

[13] Kenya National Bureau of Statistics [KNBS] (2019) Economic Survey 2019. Republic of Kenya.

[14] Kenya Sugar Board [KSB] (2010) The Kenya Sugar Industry Value Chain Analysis: Analysis of the Production and Marketing Costs for Sugarcane and Sugar Related Products.

http://www.kenyasugar.co.ke/index.php?option=com_k2\&view=item\&layout=item \&id=61\&Itemid=184\&lang=en

[15] Ndii, D. (2019) Stakeholders Smallholders: The Political Economy of Kenya's Sugar Industry.

https://www.theeastafricanreview.info/op-eds/2019/02/04/steakholders-vs-smallhol ders-the-political-economy-of-kenyas-sugar-industry/

[16] Agriculture and Food Authority [AFA] (2018) Sugar Directorate. Sugar Market Newsletter. https://agricultureauthority.go.ke/?page_id=119

[17] Millennium Cities Initiative (2008) MCI and VCC Working Paper Series on Investment in the Millennium Cities No. 06/2008.

[18] Chisanga, B., Gathiaka, J., Nguruse, G., Onyancha, S. and Vilakazi, T. (2014) Competition in the Regional Sugar Sector: The Case of Kenya, South Africa, Tanzania and Zambia. Journal of Agriculture, 2, 25-39.

[19] Odek, O., Kegode, P. and Ochola, S. (2003) The Challenges and Way Forward for the Sugar Sub-Sector in Kenya. Friedrich Ebert Stiftung. Nairobi.

[20] Global Agricultural Information Network (2016) Kenya Annual Sugar Report.

[21] Kenya Anti-Corruption Commission [KACC] (2010) Review of the Policy, Legal and Regulatory Framework for the Sugar Sub-Sector in Kenya. A Case Study of Governance Controversies Affecting the Sub-Sector. Nairobi, Republic of Kenya.

[22] Kenya National Assembly [KNA] (2019) Report on Implementation Status of the Departmental Committee on Agriculture, Livestock and Cooperatives' Report on the Petition on and Inquiry into the Crisis Facing the Sugar Industry in Kenya. Twelfth Parliament, 3rd Session, Nairobi, June 2019.

[23] Wawire, N.W., Jamoza, J.E., Shiundu R., Kipruto K.B. and Chepkwony, P. (2006) Identification and Ranking of Zonal Sugarcane Production Constraints in Kenya. KESREF Technical Bulletin, No. 1, 78-102.

[24] Odenya, J.O., Onginjo, E.O. and Kebenney, F. (2008) A Report on the Baseline Survey on the Sugarcane Production in Kenya. Kenya Sugar Research Foundation.

[25] Wawire, N.W., Nyongesa, D.P., Wachira, P. and Kipruto, B. (2002) The Effects of Continuous Land Sub-Division on Cane Production in Kenya: Economic Plot Size, Distance and Land Leasing Issues in the Sugar Industry. Kenya Sugar Research Foundation.

[26] National Environment Management Authority [NEMA] (2017) State of Coast Re- 
port for Kenya. Second Edition. Enhancing Integrated Management of Coastal and Marine Resources in Kenya. NEMA, Kenya.

[27] Temper, L. (2008) Let Them Eat Sugar: Life and Livelihood in Kenya's Tana Delta. University of Barcelona, Barcelona.

[28] Mireri, C., Onjala, J. and Oguge, N. (2013) Baseline Study for Sugar Agribusiness in Kenya. Kenya Sugar Board.

[29] Birdlife International (2008) Sugarcane Plantations in the Tana River Delta Threaten Kenyan Birds, Biodiversity and Livelihoods.

http://www.birdlife.org/datazone/sowb/casestudy/139

[30] Government of Kenya (2018) The Crops (Sugar) (General) Regulations, 2018. Government Printer, Nairobi.

\section{Abbreviation Notation}

AFA Agriculture and Food Authority

KACC Kenya Anti-Corruption Commission

KISCOL Kwale International Sugar Company Limited

KNA Kenya National Assembly

KNBS Kenya National Bureau of Statistics

KSA Kenya Sugar Authority

KSB Kenya Sugar Board

NEMA National Environment Management Authority

SRI Sugar Research Institute 